\title{
Multiple Identities in Decentralized Spain: The Case of Catalonia
}

\author{
LUIS MORENO, ANA ARRIBA AND ARACELI SERRANO
}

Modernization brought about the idea of all-embracing state national identities rooted in both cultural and civic axes. At the turn of the twentieth century, such identities are openly questioned and have become problematic. While being corroded by the forces of globalization they are also subject to fragmentation, competition and overlapping elements of a multiple and diverse nature. Unquestionably, there is a noticeable strengthening of local, regional, national (sub-state) identities (Keating, 1996). The discontinuity and dislocation of social arrangements provide that different identities relate to each other in quite an unpredictable manner (Giddens, 1991; McCrone, 1993; Melucci, 1989).

Ethnoterritoriality refers to a conceptual dimension where conflicts and political mobilizations are developed and have as chief social actors those ethnic groups which possess a geographical underpinning. Such a spatial reference is identifiable within the boundaries of a polity, usually of a compound or plural composition (Rudolph and Thompson, 1992). In plural societies individuals are tied to cultural reference groups which might be in competition among themselves. This results in a multiplicity of sociopolitical identities, dynamic and often shared, which are not expressed explicitly. Therefore, identity markers are malleable and the intensity of their manifestation greatly depends upon contingent circumstances (Barth, 1969; Brass, 1991; Cohen, 1992; Hobsbawm and Ranger, 1983).

For social scientists the main problem arises in establishing boundaries and degrees to citizens' self-identification, and in interpreting those causes for political mobilization related to territorial identities (Anderson, 1983; Hobsbawm, 1990). In fact, identities are shared in various degrees by individuals and are subject to constant internalization by group members (Greenfeld, 1992; Smith, 1991). Furthermore, supranational levels of ascription (European, for example) can integrate state and sub-state identities in apparent conflict among themselves (1).

The revival of ethnoterritorial political movements has coincided with an increasing challenge to the centralist model of the unitary state (Keating, 1988). In the case of Spain, as in other pluriethnic states, regional decentralization and federalization seek to articulate a response to the stimuli of the diversity or plurality of society, comprising cultural/ethnic groups with differences of language, history or traditions which can also be reflected in the party system.

The persistence of a dual identity or compound nationality in Spain reveals the ambivalent nature of the internal ethnoterritorial relations that have existed in recent times. In line with cultural pluralist premises, the emphasis is placed not merely on the distinctiveness. Those relationships of interaction between the different ethnoterritorial groups within the state are also to be underlined. It has been argued that political accommodation to secure political and institutional stability in pluriethnic societies or polyarchies is almost impossible and is bound to result in either the breakup of the state or the consolidation of a type of hegemonic authoritarianism for the control of the state's unity (Dahl, 1971; Horowitz, 1985)(2). On the contrary, ethnoterritorial co-operation and agreement may not only overcome conflicts and 
divergence within plural polities but can also provide a deepening of democracy by means of a more effective access of civil society to political decision-making. In the case of Spain, this development overlaps with its internal ethnoterritorial and cultural diversity.

In the following section a succinct review and interpretation of some of the main developments in Spain's recent history will provide the reader with background for our subsequent discussion on the territorial identities in the Spanish Estado de las Autonomias ('State of Autonomies'). The last section of this article is focused on the case of Catalonia. An analysis of data on citizens' self-identification, collected monthly during the period 1990-95 (see Methodological Appendix), provides the bases for interpretations on the nature of compatibility between local/ethnoterritorial and state/national identities.

\section{UNITY AND DIVERSITY IN CONTEMPORARY SPAIN}

Spain's territorial unity has been put under strain by the centrifugal action of its ethnoterritorial and linguistic diversity, as well as by that of either weak state institutions or, sometimes, by violent central rule. Moreover, there has been a traditional lack of congruence between political and economic powers. This 'non-congruence' has traditionally nourished the centrifugal tendencies present in modern Spanish history, tendencies that found expression in a number of armed conflicts.

\section{Centre and Periphery in Post-Colonial Spain}

With the Restoration of the monarchy (1876-1923), and the centralizing dictatorship of Primo de Rivera (1923-30) which followed, a new statist attempt to impose uniformity on the country reared its head, but it ended in failure.

A combination of disparity in Catalonia's social structures (3) and impoverished rural Spain was an important cause, among others, of the rise of Catalan nationalism. In particular, the differences between Spain's two major cities, Madrid and Barcelona, became increasingly evident (4).

The Basque Nationalist Party, founded in 1895 , underlined traditional community values in opposition to bourgeois industrial society, the effects of which included a considerable influx into the Basque country of migrants from the rest of Spain. Basque nativism of a racist character was the ideological basis of early Basque nationalism, which combined with powerful populist elements and religious exclusivism to produce a discourse quite distinct from that of Catalan nationalism. This latter ideology was more intellectual and has always been less secessionist in character. The reason behind its having provoked greater resistance than Basque nationalism ought perhaps to be sought in the fact that it offered an alternative view of Spain, something which Basque nationalism has frequently turned its back on. Both nationalisms, however, could be seen as political manifestations of a vigorous and prosperous periphery that contrasted with the centralism of the Spanish state to which it was subordinated.

In other Spanish territories, regionalism came in different forms, in many cases stimulated by the action of the Catalan and Basque movements, and reflected the ethnoterritorial diversity of plural Spain. Partly as a consequence of the federal experience of the First Republic (1873), there were clamours for recognition in Galicia, Valencia, Andalusia and Asturias. Chronologically, the appearance of explicit claims for regional autonomy in contemporary Spanish politics occurred in the years just before and just after the turn of the present century. 
In spite of its short existence, the Second Republic (1931-39) contributed largely to the resolution of ethnoterritorial conflict. One of the most notable improvements was the constitutional design of the state as a regional model, situated somewhere between a unitary and a federal state. This conceded statutes of autonomy to Catalonia, 5 the Basque Country (6) and Galicia (7). There is no doubt that the regional autonomy question also played a fundamental part in the political polarization process before the Civil War (1936-9). Even within the republican forces the regionalist-centralist issue created innumerable controversies.

The autonomist process, though incipient, was spreading throughout Spain by the time the Civil War broke out. With the victory of General Franco's forces, a long period of political centralization ensued, aiming once again to create a uniform Spain.

Two of the most notable fixations of the Franco dictatorship (1939-75) were anti-communism and anti-separatism. The 'sacred unity of the homeland' was regarded as an indispensable unifying element and raison d'etre of General Franco's despotic regime. To a large extent, Francoism justified itself through its ability to suppress all forms of autonomism, regionalism and stateless nationalism. Any form of federalism or wish for home rule was understood by the Franco regime as 'separatism'.

The Francoist conception of national unity, at the expense of the cultural and ethnic variety of the people of Spain, degenerated into an obsessive dogma. In fact, the linguistic and cultural oppression of Francoism stimulated peripheral regionalism and nationalism in Spain (Giner, 1984). From the 1960 s onward, the autonomist process intensified owing much of its emergence to the nature of Francoism. During the final years of its existence, the opposition to the regime developed a compact programme for democratic rights and for the political decentralization of the Spanish state. In the so-called 'historical nationalities' in particular (Catalonia, Galicia and the Basque Country), the forces opposed to Francoism were able to articulate a political discourse denouncing the absence of democracy and the continuous official attacks on their identities. In these communities, democratic and ethnoterritorial vindication went hand in hand. Thus, the ideology of autonomism and political decentralization made its way into Spanish democratic political consciousness.

The 1978 Constitution and the Decentralization of Power

After Franco's death in 1975, the transitional process to democracy began in earnest. The democratic parties did not have a clear-cut model for the type of decentralized state they broadly advocated. However, the majority wanted home rule for all the Spanish nationalities and regions. The constitutional expression of such a strong platform constituted a major political challenge, for Spanish modern history had witnessed tragic failures where ethnicity and the territorial sharing of power were concerned.

The broad party political consensus which made the drawing up of the 1978 Constitution possible also brought with it an element of ambiguity in the formulation of the territorial organization of the Spanish state. In fact, two different conceptions of Spain, which had traditionally confronted each other, were formulated. Subsequently, a middle way was negotiated and explicitly recognized by the Constitution: on the one hand, the idea of an indivisible and solely Spanish nation-state; on the other, a concept of Spain as an ensemble of diverse peoples, historic nationalities and regions. 
The 1978 Spanish Constitution made it possible for the Autonomous Communities to be selfgoverning. It depended on the political will expressed by the inhabitants of each nationality or region, or by their political representatives. It also made it possible for the degree of selfgovernment to be wide or restricted according to the wishes of the nationalities and regions. Conservatives, Centrists, Nationalists, Socialists and Communists hammered out an agreement of a type of 'quasi' or 'asymmetrical' federalism with the implementation of the Estado de las Autonomias. The accepted solution took the form of an unwritten pledge to extend the procedures of political transaction and consociationalism into the future.

This open model of 'asymmetrical federalism' did not presuppose the ways and means by which the different spatial entities could finally be articulated. Thus, an implicit desire was expressed by the 'Fathers' of the 1978 Constitution to provide the procedures and degrees of self-government to be pursued by the nationalities and regions while allowing them a high degree of flexibility (8)The formulation of a clear division of powers based upon 'orthodox' federal techniques was, however, avoided. The construction of the Estado de las Autonomias had to follow a 'topdown' process of decentralization (Linz, 1989). This way of doing things is just one of the options available in the development of federal systems. The result at the close of the twentieth century is not much more than a series of practices of a federal nature involving a series of politically competitive units. Even so, the full development of multilateral decision-making, or a genuine common exercise of three-tier government action (at central, regional and local levels simultaneously), remains to be seen.

The decentralization process embodied in the 1978 Spanish Constitution has undergone a long period of consolidation. Support for autonomy, apart from the Basque and Catalan communities, has been particularly strong in Andalusia and other regions (the Canary Islands, Galicia and Valencia) (9). Certainly it is the case that some regions were 'encouraged' by their most prominent political parties to enter into the autonomist process. Some areas with no self-governing tradition whatsoever were suddenly inspired to claim autonomic rights. These were mainly uni-provincial communities lacking ethnoterritorial specificity, unless they recognized their origins elsewhere, such as the cases of Cantabria, La Rioja, and even the province of Madrid. In some cases, the decentralization process has entailed a break-off from the ethnoterritorial base of certain provinces. One of the consequences of this has been the creation of hybrids such as Castille-La Mancha or Castille and Leon.

The cases of Navarre and the Catalan Countries (Paisos Catalans) (10) have exemplified the difficulties in setting clear boundaries in certain regions. For some Basque nationalists, including ETA separatists, Navarre is an integral part of their country that can never be given up (11). For most of the people of Navarre, however, the old kingdom has more than enough right to its own constitution. The Catalan Countries are perceived as a whole with a composite identity deserving political treatment as such by not just pan Catalanist parties, but by the usually more cautious President of the Catalan Government, Jordi Pujol, in his federalist understanding of Spain (12).

In general terms, at the end of this century, it can be said that the decentralization process has been assimilated by most Spaniards. This reality legitimates its political expression. However, although far from over, the decentralization process needs to gradually adapt to new forms of intergovernmental relations, especially at the level of institutional collaboration (13). The articulation of institutional relations involving shared powers and responsibilities lies at the very base of the federal-like ethnoterritorial relations of Spain. 


\section{DUAL IDENTITY IN SPAIN}

Spain is a national state made up of nationalities and regions (Comunidades Autonomas). Both its ambivalent state-building and national-formation explain, to a considerable degree, the duality in which citizens identify themselves. This concept of dual identity - or compound nationality - concerns the way citizens identify themselves in the Comunidades Autonomas (Autonomous Communities). It incorporates - in variable proportions, individually or subjectively asserted - the local/ethnoterritorial self-ascribed identity and the state/national identity produced by political integration in the state-building process. As a result of this, citizens share their institutional loyalties at both levels of political legitimacy without any apparent fracture between them (Moreno, 1986, 1988).

The concept of dual identity provides a useful element for the understanding and assessment of political conflict and ethnoterritorial politics in contemporary Spain. It also provides a useful methodological tool for the measurement and interpretation of the degree of internal consent and dissent in decentralized Spain. Let us recall, as Juan Linz (1975: 423) has observed, that: 'Spain today is a state for all Spaniards, a nation-state for a large part of the Spanish population, and only a state but not a nation for important minorities'.

In general, the quest for self-government by stateless nations and regions is in full accordance with the variable manifestation of this duality: the more the primordial ethnoterritorial identity prevails upon modern state identity, the higher the demands for political autonomy. Conversely, the stronger the state-national identity is, the less likely it would be for ethnoterritorial conflict to appear. In an extreme case, the complete absence of one of the two elements of dual identity would lead to a socio-political fracture in the pluriethnic state, and demands for self-government would probably take the form of self-determination. In other words, when citizens in a sub-state community identify themselves in an exclusive manner, the institutional outcome of such antagonism will also tend to be exclusive.

The task of identifying and measuring the notion of dual identity/compound nationality is far from simple. The changing nature implicit in such a duality complicates matters. Thus, positive perceptions on the action of the Spanish state by members of the Comunidades Autonomas can result in a loosening of their self-ascribed local identity and a corresponding reinforcement of their sense of membership within the Spanish nation-state, and vice versa. Obviously, the dual identity concept modifies its constituent elements according to subjective perceptions and evaluations. In fact the reinforcement of one identity upon the other may well result in the complete disappearance of such a compound nationality as it now stands.

The existence of this compound nationality in most of the Spanish Comunidades Autonomas had its institutional correlation in the setting-up of regional legislatures and governments in the 1980s, which have not only preserved local identities but have also projected the political aspirations of these sub-state communities. In the past the maintenance of regional ethnocultural peculiarities in Spain was the result, at least partially, of the inefficiency and weakness of the centralizing forces. Since the approval by popular referendum of the 1978 Constitution, such cultural diversity has been greatly encouraged by the governments of the Comunidades Autonomas which have given priority to cultural, educational, linguistic and mass media policies (Giner and Moreno, 1990). The role of these self-governing institutions in the production and re-production of local identities is very important. Further, common elements of language and history in two or more Comunidades Autonomas make the task of interpreting the interplay of identities in boundary regions even more complex (such as Paisos 
Catalans referring to Catalonia, Balearic Islands and Valencia, or the cases of the Basque Country and Navarre).

As the 1978 Spanish Constitution recognizes, the Basque Country, Catalonia and Galicia are three 'historical nationalities' within the Spanish state. They are seen, therefore, as minority stateless nations characterized by a 'differential fact' \{hecho diferencial) or, in other words, as 'distinct societies'. After 15 years of widespread political decentralization, the political and spatial reorganization brought about by the progressive consolidation of the Spanish Estado de las Autonomias is in line with a model of 'multiple ethnoterritorial concurrence' (Moreno, $1994,1995)$. This model relates socio-political ethnoterritorial mobilization to the competitive interplay among Spanish nationalities and regions pursuing political and economic power, as well as to the achieving legitimization for their institutional development.

In all 17 Comunidades Autonomas there is a high proportion of citizens who claim some form of dual identity (see Methodological Appendix). As shown in Figure 1, aggregate data in percentages concerning self-identification by Spaniards in the period October 1990-June 1995 indicate that a degree of duality has been expressed by around 70 per cent of the total Categories (2) 'More Andalusian, Basque, Catalan, Castillian, etc., than Spanish'; (3) 'As much Andalusian, Basque, Catalan, Castillian, etc., as Spanish'; and (4) 'More Spanish than Andalusian, Basque, Catalan, Castillian, etc.'. However, differences are noticeable in some nationalities and regions (Navarre, Canary Islands, Asturias and Galicia show higher percentages of dual identity).

Approximately 30 per cent of all Spaniards have expressed a single identity with respect to either state/national or local/ethnoterritorial dimensions ('Only Spanish', or 'Only Andalusian, Basque, Catalan Castillian, etc.'). The consistency in the results provided by The Spanish Centre for Studies on Social Reality \{Centro de Estudios de la Realidad Social (CIRES) periodical surveys is to be underlined (NB. The maximum deviation is a four-point percentage). Although Figure 1 reproduces aggregated data, the same percentage consistency is observable on analyzing results by regions.

Figure 2 data reproduces data regarding all 17 Comunidades Autonomas. Note that in the Basque Country and the Canary Islands single ethnoterritorial identity is higher than 20 per cent. Likewise, in Catalonia, the Balearic Islands and Asturias single local self-identification is higher than ten per cent of the total of survey respondents. Spanish single identity is more significant in Castille-La Mancha, Madrid, Cantabria, Valencia and Castille-Leon (above 30 per cent in all cases).

Shared identity in Spain as a whole is prevalent: (category 3: 'As much Andalusian, Basque, Catalan, Castillian, etc. as Spanish'). In some Autonomous Communities percentages of shared identity reach over 75 per cent (La Rioja), or 50 per cent (Andalusia, Extremadura, Navarre, and Aragon).

'Don't Know/No answer' figures are considerably low as compared to the usual percentages produced in this kind of surveys. This finding seems to confirm the lack of indifference among Spaniards on the cultural and institutional implications of self-identification and the process of decentralization. The only exception is the Basque Country ( 6 per cent) where the climate of political violence induced by ETA terrorism (14) and the climate of civil confrontation could have had obvious impact in this category. 
Some Comunidades Autonomas may be labelled as 'exclusivist' (Basque Country and Canary Islands), some more 'localist' (Navarre and Galicia) and some others as 'balanced' (Catalonia and Asturias). By 'exclusivist' we refer to those Autonomous Communities with a level of single ethnoterritorial identity noticeably higher than the rest of the Comunidades. 'Localist' corresponds to a predominance of the combination of both single ethnoterritorial and local dual categories - categories (1) 'Only Andalusian, Basque, Catalan, Castillian, etc.; and (2) 'More Andalusian, Basque, Catalan, Castillian,... than Spanish). 'Balanced' refers to those Comunidades where single ethnoterritorial and Spanish categories are on equal terms, alongside an important manifestation of 'shared' identities. The espanolistas Communities include regions where Spanish single identity is predominant (Balearic Islands, both Castilles, Madrid, Cantabria and Valencia).

\section{THE CATALAN CASE}

By the time General Franco died (1975), several unitary or cross-party organizations, which had been channelling the increasing popular pressure for the recovery of democracy and home rule, already existed in Catalonia.Is The popular aspirations for home rule were widely expressed. In the campaign for the first General Elections held in Spain since February 1936, and which took place on 15 June 1977, 13 out of the 20 electoral candidatures committed themselves to home rule. Note that 80 per cent of the elected candidatures to the Congress of Deputies (Lower House), and all but one of the elected candidates for the Senate (Upper House), were committed to political autonomy for Catalonia.

Solely the parties, which explicitly define themselves as such, cannot claim the label 'national' or 'nationalist'. Both PSC (Partit dels Socialistes de Catalunya, integrated within the Spanish PSOE) and PSUC (Partit Socialista Unificat de Catalunya, brother organization of the Spanish Communist Party) have been not only Catalan national organizations but also main catalyzers in the achievement of self-government in Catalonia. Note also that Catalan nationalists of the coalition CiU have steadily refused secessionism. Catalan nationalism has always attempted to influence Spanish politics and has repeatedly avoided limiting itself to mere local activities.

As more specifically regards our discussion, the compatibility of identities in Catalonia is the most characteristic feature to be underlined. Thus, Catalonia can be labelled as a 'balanced' Comunidad Autonoma as shown in the following percentages for the aggregated data of the period 1990-95: (1) 'Only Catalan, 12.5 per cent; (2) 'More Catalan than Spanish', 18.9 per cent; (3) 'As much Catalan as Spanish', 38.9 per cent; (4) 'More Spanish than Catalan', 9.8 per cent; (5) 'Only Spanish', 16.7 percent; (6) Don't know/No answer, 3.1. (Figure 3 illustrates the evolution during 1990-95).

As also happens in the Spanish context as a whole, data from the Catalan case shows a degree of consistency of the values produced in each of the self-identification categories throughout the period under analysis. Slight annual variations are of little relevance.

In order to make interpretations of the available data, we have considered advisable the use of a multivariate analysis. The independent variables, which have been taken into account by the Spanish Centre for Studies on Social Reality (Centro de Estudios de la Realidad Social - CIRES) surveys are: 'Place of Birth'; 'Education'; 'Social Class'; 'Income'; 'Economic Activity'; 'Size of Town'; 'Occupation'; 'Ideology'; 'Age'; and 'Religiosity' (See Methodological Appendix). We are aware of the fact that these variables do not exhaust the possibilities for further research. In particular we believe that both the place of birth of the parents of the surveyed respondents, and the competence in the use of the Catalan language, are two important indicators to be 
taken into account in future studies.16 However, the variables now considered offer a set of data that is relevant in order to carry out interpretations always subject to further contrast.

We have carried out a segmentation analysis on the basis that it allows the construction of models where a considerable number of variables are taken into account. It also makes possible the setting of basic typologies with regard to the variable being used. The results of two segmentation analyses are presented in this article. Categories of identities have been grouped as follows:

(a) Catalan identity ('Only Catalan' and 'More Catalan than Spanish'), Spanish identity ('Only Spanish' and 'More Spanish than Catalan'), and Shared identity ('As much Catalan as Spanish').

(b) Exclusive identity ('Only Spanish' and 'Only Catalan'); and Dual Identity ('More Catalan than Spanish', 'As much Catalan as Spanish', and 'More Spanish than Catalan').

Associations among different variables are worth exploring. However, in our analyses we concentrate in those with a higher degree of concomitance in the various levels of segmentation. These variables are reproduced in Figures 4 and 5.

After the examination of all data collected during the 1990-95 period the variable 'Place of birth' appears to be the most relevant concerning Catalans' self-identification. Let us remember that since the beginning of the century, but mainly from the 1960s onwards, immigration from poorer regions of Spain has been very important in Catalonia. Between 1900 and 1950, three-quarters of all the demographic growth in Catalonia was due to immigration. In 1975, 38.3 per cent of Catalan residents had been born outside Catalonia. In the period $1941-80$, as many as $1,655,149$ immigrants established themselves in Catalonia. They were mostly job-seekers, nonskilled and with low degrees of formal education, and came from other parts of Spain. At present, around a third of all legal residents in Catalonia are immigrants. However, it would be a mistake to speak of a homogeneous social group or category vis-a-vis native Catalans (Miguelez and Sole, 1987). This aspect seems to be confirmed by our analysis of the CIRES data.

As Figure 4 shows almost ten per cent of respondents born outside Catalonia expressed a 'Catalan identity' as compared to 41.2 per cent of those born in Catalonia. 'Spanish identity' was prevalent among 51 per cent of immigrants, in contrast to 15 per cent of respondents born in Catalonia. Note that the latter group also incorporates a high percentage of 'shared identity' ( 40.7 per cent). This feature can be interpreted as a reflection of certain traditions of political tolerance and social integration from the native population with regard to the immigrant population.

In contrast with the often-uneasy relationships between native and immigrant sectors of population in other parts of Europe (for example, Bavaria, Flanders, Northern Italy), Catalonia offers an example of high social integration between both natives and immigrants. Both collectives seem to be interwoven in various degrees and manifestations. Integration and tolerance are among the main features present in Catalonia's social life. There is a widespread assumption that internal differences are articulated in a common project, and that syncretism is a constituent element of Catalonia's national character. However, the evolution of identities of second and third generations of immigrants remains to be analyzed as an important element for future research. Some nationalists are of the opinion that those Catalans showing 'shared' identities should opt in the future for a higher degree of local catalanidad: 'Patriotic bigamy is not a good solution for the problems of survival of the stateless nations' (17). 
The second most relevant variable is 'Education'. Note that while citizens born in Catalonia are over-represented in high educational levels, those born outside Catalonia concentrate primarily in low levels. A pattern shared by both immigrant and autochthonous collectives is that 'Catalan identity' increases with the level of education. The role played by the intelligentsia and other professional elites in the diffusion of national sentiments is a wellknown sociological fact. Numerous studies have insisted on the importance of the educational system for the consolidation and reproduction of national consciousness. Likewise, population groups with better access to formal instruction are more inclined to 'nationalistic' views in the context of minority nations within Western plural states. This feature is also applicable to the Spanish context. As regards Catalonia, the analysis of CIRES data corroborates previous findings along these lines. Let us emphasize that Catalan has often been considered to be a language of 'culture' which has traditionally conveyed the transmission of local idiosyncrasies. It comes as no surprise that those Catalans with higher degrees of formal education also show a greater disposition to 'Catalan identity'. On the other hand, CIRES data also confirms that individuals with a low level of education, the unskilled labour force, and the unemployed are more in line with 'Spanish identity' positions.

With ageing, a more perceived degree of 'Catalan identity' is also noticeable (in both immigrant and native cases, and correlates with the level of education). This association seems to validate the assumption that socialization forces are main responsible for identity formation. Degrees of 'shared identities' are evenly represented in most sub-groups with the exception already mentioned of the higher degree expressed by the native population.

Note that Catalanisme, or early Catalan nationalism, was mainly attributed to the political mobilization of Catalonia's bourgeoisie and middle classes during the second half of the nineteenth century (Sole-Tura, 1967). 'Social Class' is, thus, a relevant variable to be taken into consideration in the case of Catalonia. This observation seems to be corroborated by the analysis of the CIRES data. An increase in the importance of 'Catalan identity' is noticeable on ascending in the social class structure. Two groups regarding the predominance of 'Catalan identity' within the autochthonous population can be identified: (a) Those with higher levels of education (and employed); and (b) Those upper-class groups with secondary education levels. These findings seem to underline the important role played by collective internalization of historical events and by ideological traditions in the development of national identities.

We can conclude that there are two the main considerations that should be taken into account in order to explain trend changes in future Catalans' self- identification: (a) generational differences related to educational tuition, and (b) differences in educational levels and social class

Analysis (b)

Concerning 'duality' of self-identification by Catalans the main results are reproduced in Figure 5.

Yet again, the first and foremost segmenting variable is that related to 'Place of birth'. A reiterative pattern is apparent for citizens born in Catalonia to be more in line with 'dual identities'. Apart from this finding no other disparities are worth mentioning with respect to 'duality' as regards other variables. However, two peculiarities can be pointed out:

- Less than 30 years-of-age immigrants with a low educational level represent the group with the least degree of 'dual identity', They tend to identify themselves exclusively: 'Only Spanish' 
or 'Only Catalan'. Likewise, the degree of 'duality' also grows with ageing for those citizens born outside Catalonia. This indicator is consistent with the patterns of inclusion visible in Catalan society regarding immigration.

- With relation to the native population, duality increases inversely from higher to lower social classes. In other words, better-off citizens (also, in many cases, with higher levels of formal education) tends to be less 'dual' and more Catalan in their self-identification (Note, however, that percentage differences are small). This seems to corroborate the importance of the Catalanist tradition in the contemporary manifestations of self-identification.

As far as 'dual identity' is concerned the two most heterogeneous groups

are:

(1) Lower and lower-middle classes of native Catalans (75.5 per cent of whom identify themselves in the three dual categories);

(2) The 18- 30 age group of citizens born outside Catalonia (38.3 per cent of whom expressed a degree of 'duality'). In this latter group processes of socialization and integration have little or no effect.

\section{Self-identification and Electoral Behaviour}

How levels of 'dual identity' translate into electoral behaviour? The answer to this question cannot be univocal following our analysis of the CIRES data. In fact, we have not been able to make cross-tabulation between these two variables simply because the available data is lacking. The establishment of a direct correlation between self-identification and voting patterns cannot be deduced from the segmentation analyses we have dealt with in this article. We are convinced that the examination of these two variables would prove to provide fruitful explanations. Notwithstanding, and taking into account some partial findings of previous studies (Moreno and Arriba, 1996), a degree of 'tactical voting' by Catalans can be hypothesized and argued for.

Table 1, which includes the electoral results produced in Catalonia during 1977-96, reveals interesting information regarding this point. Note that a relatively small but significant sector of electors votes differently according to the nature of the election (local/municipal, Catalan Parliament, or Spanish Parliament). Note also that 'duality' reaches its highest ratios with respect to the ideology categories of 'Centre' (77.6 and 65.6 per cent, respectively) and 'Centre-Left (75.4 and 65.7 per cent, respectively). It seems more than plausible to consider the hypothesis that a number of voters, who self-ascribed themselves into the two ideological categories referred to above, vote to the centre-right nationalist coalition Convergencia i Unio, in the Catalan Elections, while casting their votes for the centre-left Socialists in both local/municipal and Spanish elections.

Further research should substantiate these interpretations. Such studies are crucial for the purpose of distinguishing electoral sub-systems. In Spain, political colouring of local, regional and central institutions is increasingly dependent on the changing electoral support for parties operating at the various levels of government. Multiple identities seem to have a significant input in the way electors cast their votes. Undoubtedly, this 'tactical voting' will have farreaching implications for the general governance in Spain and, in particular, with respect to the processes of policy making and implementation. The achievement of a culture of 
intergovernmental relations in the three-tier system of government in Spain appears to be one of the main political challenges in the years to come.

\section{CONCLUSION}

As regards multiple identities in Spain, the consistency of the results provided by CIRES periodical surveys should be underlined. This pattern is also applicable on analyzing results at the regional level. However, findings at the regional level show a degree of diversity in citizens' self-identification. A common feature to all Comunidades Autonomas is the widespread manifestation of dual identities, and in particular those sharing both Spanish and localethnoterritorial identities at a similar degree. It should also be pointed out that less than a third of all Spaniards express a single or exclusive identity ('Only Andalusian, Basque, Catalan, Castillian, etc.', or 'Only Spanish').

The case of Catalonia illustrates the comparability of both Catalan and dual categories. Furthermore, both segmentation analyses have confirmed some findings of previous studies (Serrano, 1995; Moreno and Arriba, 1996). The most relevant one is that self-identification by Catalans shows a considerable degree of duality. It is also important to point out that the variables 'Place of birth' and 'Education' are central to explain differences in the way Catalan identify themselves. There is also an observable trend indicating that as social class lowers so does the number of citizens expressing a 'Catalan identity'

On analyzing multiple identities territorial and functional elements are intertwined in a complex way. The changing nature of their interaction requires the carrying of further research on consistent bases so that new insights and plausible explanations can be proposed.

\section{METHODOLOGICAL APPENDIX CIRESData}

The Spanish Centre for Studies on Social Reality \{Centro de Estudios de la Realidad Social, CIRES) provides research teams with data from national surveys. From October 1990 until June 1995, 46 surveys have been carried out by CIRES on monthly bases (except for the summer months) covering several monographic questions. The monthly sample size is 1,200 adults aged 18 and over (NB: The sample for June 1991 was 2,400). The survey poll is representative of the Spanish population over the age of 18 . Monthly samples are random and stratified by regions (Comunidades Autonomas) and municipalities according to size.

The periodical repetition of part of the questionnaire allows data aggregation for statistical purposes. In this way, larger samples can be obtained with a higher degree of reliability, and population areas such as Catalonia can be also analyzed. For the purposes of our paper, data from 46 survey polls have been aggregated resulting in a sample of 56,400 cases. The size of Catalan sample is 9,126 cases.

This paper analyzes the identity expressed by Catalan citizens based on the question addressed to them in the successive polls, which is reproduced as follows:

Question: 'In general, would you say that you feel....

1. Only Catalan'

2. More Catalan than Spanish'

3. As much Catalan as Spanish'

4. More Spanish than Catalan' 


\section{Only Spanish'}

\section{Don't know'}

\section{No answer'}

For the purpose of our study, answers have been aggregated according to the following categories:

(a) Single Identity (values 1 and 5).

Dual Identity (values 2, 3 and 4).

(Values 6 and 7 have been aggregated).

(b) Catalan Identity (values 1 and 2).

Shared Identity (value 3).

Spanish Identity (values 4 and 5).

(Values 6 and 7 have been aggregated).

\section{Segmentation analysis}

Segmentation analysis is based on the chi-square research technique. It allows the selection of relevant variables and provides a description of the differences that diverse sample groups can manifest in a given category.

A number of independent variables are selected as predictors, along with the dependent variable subject of study. A population is divided into homogeneous groups which are different from each other with respect to the dependent variable to be measured. Within a dependent variable, subjects are classified within groups with characteristics significantly different and based on the chi-squared statistical logic for the selection of the best available predictors (CHAID). This technique carries out the merging by categories of those independent variables with a similar profile in relation to the dependent variable. A first segmentation is carried out with the best predictor, and successive segmentations with the resulting groups follow. The test is continued only if resulting differences are statistically significant (Escobar, 1992).

The variables used as predictors in our segmentation research are:

- Place of birth (Born 'In Catalonia' or 'Outside Catalonia')

- Educational level ('Lower', 'Middle' or 'Higher').

- Social Class ('Lower', 'Lower Middle Class', 'Middle Class', 'Upper Middle' or 'Upper'. This is a subjective indicator (self-perceived)).

- Occupation ('Non-active', 'Unemployed' or 'Occupied'). Age (Four categories: 18-30, 31-

44,45-64, 65 and over). • Religiosity ('No or little practice', 'Middle', and 'Active')

- Size of the place of residence ('Less than 5000', '5001-50000', '50001-250000', and '250000 and over')

- Sex 
- Economic sector ('Primary', 'Secondary', and 'Tertiary') Ideology ('Extreme Right', 'Right', 'Centre', 'Left', and 'Extreme Left').

- Monthly income ('Less than 75,000 PTAs', 'Less than 150,000 PTAs', 'Less than 275,000ptas', and 'Less than 450,000 PTAs'.)

\section{NOTES}

1. According to Pérez Agote, the fact that two identities can be subsumed in one referred to a larger entity larger does not preclude their possible relationship of incompatibility (1994: 311). That would be the case, for example, of both Basque and Spanish exclusive forms of selfidentification within the European context.

2. Robert Dahl's position is in line with the views of Ernest Barker who also regarded political secessionism and authoritarianism as the two viable options in ethnocultural and pluralist polyarchies. See Walker Connor (1994: 124), and Juan Linz (1973: 103-4).

3. On the question of the social structure of Catalonia, see Giner's monograph (1980).

4. Between 1877 and 1920, the proportion of industrial workers in Madrid over the city's total working population grew considerably from 18.4 to $42.5 \%$, but remained behind Barcelona ( $37.1 \%$ and 1877 to $54 \%$ in 1920 . Perhaps it is more significant to note that the proportion of 'unproductive' middle classes in Madrid, consisting of civil servants, members of the Armed Forces and domestic staff (23.6\% in 1877 and $15.3 \%$ in 1920), was greater than that of Barcelona (5.9\% in 1877 and 5\% in 1920). (Data taken from Linz, 1967: 209).

5. On 14 April 1931 the Spanish Second Republic was proclaimed. On the same day the Catalan nationalist leader, Francesc Macià, declared a Catalan Republic and the creation of an Iberian Confederation. After negotiations, the Generalität was re-established. The Generalitat is Catalonia's government, of medieval origin.

6. Three days after the proclamation of the Second Republic, an assembly of Basque mayors gathered by José Antonio Aguirre, leader of the Basque Nationalist Party, claimed their right to autonomy within a Spanish federal republic, by the historic Oak of Gernika. Nevertheless, parliamentary approval of the proposal was thornier than the Catalan statute.

7. In Galicia, the Organizatión Regional Gallega Autônoma (ORGA, Autonomous Regional Organization of Galicia), led by Santiago Casares Quiroga, had instigated the drafting of a proposal for autonomy. On June 28th 1936, a referendum was held and around $70 \%$ of the Galician electorate voted. The final result was 991,476 votes for and 6,805 against.

8. The popular expression 'coffee for all' reflected this desire to avoid coercing the autonomist aspirations of other Spanish regions.

9. After 15 years of deep political and administrative decentralization, the judgement of the process made by the Spaniards was reflected in a survey poll according to the following percentages: $11 \%$ ('Totally positive'), 49\% ('More positive than negative'), 21\% ('More negative than positive'), 10\% ('Totally negative'), and 9\% ('Don't Knows') (El País, 19 Nov. 1995).

10. Expression used by some to denote the Principate of Catalonia, the old Kingdom of Valencia, and the Balearic Islands. Frequently included is Rosselló (Roussillon), in southern France, where Catalan is spoken. 
11. This is the claim made by both Herri Batasuna, the political branch of ETA, and ETA itself. It is one of the five demands set by these radical separatists in order to negotiate with the Spanish state a permanent ceasefire.

12. 'In the specific case of Spain I could conceivably be a federalist, if the federation was based on genuine and authentic nationalities of the state, viz. Euskadi [Basque Country], Galicia, the whole of Castille, and the Catalan Countries (or just Catalonia, if Valencia and the Islands ... rejected being associated with the Principate)'. (J. Pujol, 1980: 26).

13. According to 1990 data, most Spaniards were of the opinion that relations between autonomous governments and central government should be 'collaborative' (80.7\%), and involving 'shared responsibilities' (58.2\%) (M. García Ferrando et al, 1994: 113).

14. According to the ex-ETA member, Francisco Letamendía, in the period of democratization in Spain after the death of Franco (1977-79), the terrorist organization witnessed an increasing political isolationism in the Basque Country: 'The degree of physical violence which the armed nucleus (of ETA) needed to develop in order to maintain the cohesion of the nationalist which legitimates it was much greater than that exerted during the era of Francoism' (1994: 261).

15. The Assemblea de Catalunya, set up in 1971, genuinely reflected the struggles against both dictatorship and centralist rule. Its activities followed a simple four-point programme; (a) Universal political amnesty; (b) Basic democratic liberties; (d) Home rule, according to the provisions of the 1932 Statute of Autonomy put into effect during the II Spanish Republic; and (d) Co-ordination with the rest of the Spanish peoples to re-gain democracy. This Assembly of Catalonia gathered together trade unionists, Christian democrats, Social democrats, Socialists. Communists, Urban community associations, University groups, intellectuals and ordinary people in a clandestine and highly representative movement of opposition to Franco's regime in Catalonia.

16. Note that we have carried out our interpretations taking into account secondary data produced by CIRES during the $1990-95$ period, and which do not include these two variables.

17. This was the opinion of Joaquim Triadú i Vila-Abadal, member of the Executive Committee of the nationalist party, Convergencia Democràtica de Catalunya (El País, 26 Oct. 1996).

\section{REFERENCES}

Anderson, Benedict (1983) Imagined Communities: Reflections on the Origins and Spread of Nationalism. (London: Verso).

Barth, Fredrik (ed.) (1969) Ethnic Groups and Boundaries. The Social Organization of Culture Difference (Boston: Little, Brown \& Co).

Brass, Paul (1991) Ethnicity and Nationalism. Theory and Comparison (New Delhi: Sage).

Connor, Walker (1994) Ethnonationalism. The Quest for Understanding (Princeton: Princeton University Press).

Cohen, Anthony (1992) The Symbolic Construction of Community, 1st ed., 1985 (London: Routledge). 
Dahl, Robert (1971) Polyarchy, Participation and Opposition (New Haven: Yale University Press).

Escobar, Modesto (1992) 'El análisis de segmentación: concepto e implicaciones', Working Paper 1992/31 (Madrid: CEACS-Instituto Juan March).

García Ferrando, Manuel, Eduardo López-Aranguren and Miguel Beltrán (1994) La conciencia nacional y regional en la España de las Autonomías (Madrid: CIS).

Giddens, Anthony (1991) Modernity and Post-Modernity: Self and Society in the Late Modern Age (Cambridge: Polity Press).

Giner, Salvador (1980) The Social Structure of Catalonia. The Anglo-Catalan Society Occasional Publications: University of Sheffield.

Giner, Salvador (1984) 'Ethnic Nationalism, Centre and Periphery in Spain', in Christopher Abel and Nissa Torrents (eds), Spain: Conditional Democracy (London: Croom Helm), pp.78-99.

Giner, Salvador and Luis Moreno (1990) 'Centro y periferia: La dimensión étnica de la sociedad española', in Giner, Salvador (ed.), España. Sociedad y política, (Madrid: Espasa-Calpe),pp.16997.

Greenfeld, Liah (1992) Nationalism. Five Roads to Modernity (London: Harvard University Press).

Hobsbawm, Eric (1990) Nations and Nationalism since 1780: Programme, Myth and Reality (Cambridge: Cambridge University Press).

Hobsbawm, Eric and Terence Ranger (eds) (1983) The Invention of Tradition. Cambridge: Cambridge University Press.

Horowitz, Donald (1985) Ethnic Groups in Conflict (Berkeley: University of California Press).

INE (1991) Censo de población de 1991 (Vol.1: Resultados nacionales) (Madrid: INE).

Keating, Michael (1988) State and Regional Nationalism (London: Harvester-Wheatsheaf)

Keating, Michael (1996) Nations Against the State: The New Politics of Nationalism in Quebec, Catalonia and Scotland (London: Macmillan).

Letamendía, F. (1994)) 'On Nationalisms in Situations of Conflict' [Reflections from the Basque Case], in Justo G. Beramendi, Ramón Máiz and Xosé Manuel Núñez (eds), Nationalism in Europe. Past and Presen, Vol.1 (Santiago: Universidad de Santiago de Compostela), pp.247-75).

Linz, Juan (1967) 'The Party System of Spain: Past and Future', in Seymour Martin Lipset and Stein Rokkan (eds), Building States and Nations. Models, Analyses and Data across Three Worlds (New York: Free Press), pp.197-282.

Linz, Juan (1973) 'Early State-Building and the Late Peripheral Nationalisms against the State: The Case of Spain', in Samuel Eisenstadt and Stein Rokkan (eds). Building States and Nations. Models, Analyses and Data across Three Worlds (Beverly Hills, CA: Sage), pp.32-116.

Linz, Juan (1975) 'Politics in a Multi-Lingual Society with a Dominant World Language: The Case of Spain', in Jean-Guy Savard and Richard Vigneault (eds), Les États Multilingues, Problemes et Solutions (Québec: Presses de I'Université Laval), pp.367-444. 
Linz, Juan (1989) 'Spanish Democracy and the Estado de las Autonomías', in Robert A. Goldwin, Art Kaufman and William A. Schambra (eds), Forging Unity Out of Diversity. The Approahces of Eight Nations (Washington, DC: American Enterprise Institute for Public Policy Research), pp.260-303.

McCrone, David (1993) 'British Supranational Identities: A Scottish Perspective'. Paper presented to the conference on European Identities: cultural diversity and integration in Europe since 1700, Faaborg, Denmark.

Melucci, Alberto (1989) Nomads of the Present (London: Hutchinson Radius).

Miguélez, Fausto and Solé, Carlota (1987) Classes Socials i Poder Politic a Catalunya (Barcelona: Promociones y Publicaciones Universitarias).

Moreno, Luis (1986) Decentralisation in Britain and Spain: the cases of Scotland and Catalonia. PhD thesis, University of Edinburgh.

Moreno, Luis (1988) 'Scotland and Catalonia: the Path to Home Rule', in David McCrone and Alice Brown (eds), The Scottish Government Yearbook 1988, (University of Edinburgh: Unit for the Study of Government in Scotland), pp. 166-82.

Moreno, Luis (1994) 'Ethnoterritorial Concurrence and Imperfect Federalism in Spain', in Bertus de Villiers (ed.) Evaluating Federal Systems (Cape Town: Juta), pp. 162-93.

Moreno, Luis (1995) 'Multiple Ethnoterritorial Concurrence', Nationalism and Ethnic Politics, Vol.1, No.1, pp.11-32.

Moreno, Luis (1997) Federalism: The Spanish Experience. (Pretoria: HSRC Publishers).

Moreno, Luis and Ana Arriba (1996) 'Dual Identity in Autonomous Catalonia', Scottish Affairs, No.17, pp.78-97.

Pérez-Agote, Alfonso (1994) 'Un modelo fenomenológico-genético para el análisis comparativo de la dimensión política de las identidades colectivas en el Estado de las Autonomías', in Justo G. Beramendi et al. (eds), Nationalism in Europe. Past and Present (Santiago de Compostela: Universidad de Santiago), pp.307-23.

Pujol, Jordi (1980) Construir Catalunya (Barcelona: Pòrtic). Rudolph, Joseph and Robert Thompson (eds) (1989) Ethnoterritorial Politics, Policy, and the Western World (Boulder: Lynne Rienner).

Serrano, Araceli (1995) Identitdades étnicas versus identidades cívico-territoriales como tipos ideales de identidad nacional. Discursos, actitudes y bases sociales. Una comparación entre Cataluña y País Vasco, PhD thesis, Universidad Complutense de Madrid.

Smith, Anthony (1991) National Identity (London: Penguin). Solé-Tura, Jordi (1967) Catalanisme i Revolució Burgesa (Barcelona: Ediçions 62) 